\title{
THE PEASANTRY OF THE VOLGA GERMAN REPUBLIC IN THE PERIOD OF NEW ECONOMIC POLICY
}

\author{
Ekaterina L. Furman \\ Volgograd State University, Volgograd, Russian Federation
}

\begin{abstract}
This article focuses on the main directions of governmental policy on the peasant question and also the peculiarities of its implementation on the example of the peasantry of Autonomous Soviet Socialist Republic of the Volga Germans.

Archival documents and statistics show the position of the peasantry during the October Revolution and the Russian Civil War. It has been found that the collective farms (cooperatives, communes and associations for the joint cultivation of the land) were the most acceptable form of association under conditions of poverty in villages in the lean years. They allowed accumulating joint efforts and waiting for the next harvest even under the lack of inventory.

The author comes to the conclusion that governmental interventions in the agricultural sector (land management, the introduction of the Unified Agricultural Tax, the distribution of breeding seed loan, the implementation of credit policy, etc.) was adapted to the interests, primarily to the poorest ones in villages. In conjunction with a very meager budget of the Republic allocated for the development of agriculture, state power sought to solve the problems of the peasant population at the expense of redistribution from the rich peasants to the poorest ones. In this case the main tax burden laid on the proactive and strong part of the village (peasants of average means and substantial farmers) that as a result neutralized all attempts to eradicate peasant debt and to generate financial flows for technical re-equipment of the village and intensification of the agricultural production.

Key words: German peasantry, agricultural production, land management activities, lean years, council of states.

Citation. Furman E.L. The Peasantry of the Volga German Republic in the Period of New Economic Policy. Vestnik Volgogradskogo gosudarstvennogo universiteta. Serija 4, Istorija. Regionovedenie. Mezhdunarodnye otnoshenija [Science Journal of Volgograd State University. History. Area Studies. International Relations], 2017, vol. 22, no. 3, pp. 112-125. (in Russian). DOI: https://doi.org/10.15688/jvolsu4.2017.3.10.
\end{abstract}

\section{КРЕСТЬЯНСТВО РЕСПУБЛИКИ НЕМЦЕВ ПОВОЛЖЬЯ В ПЕРИОД НОВОЙ ЭКОНОМИЧЕСКОЙ ПОЛИТИКИ}

\author{
Екатерина Львовна Фурман \\ Волгоградский государственный университет, г. Волгоград, Российская Федерация
}

\begin{abstract}
Аннотация. В статье характеризуется положение крестьянства и особенности реализации государственной политики в аграрной сфере в период нэпа на территории Немреспублики. В процессе исследования автор приходит к выводу о том, что государственные мероприятия в аграрном секторе (землеустройство, введение единого сельскохозяйственного налога, распределение селекционной семенной ссуды, осуществ궁 ление кредитной политики и др.) проводились с учетом интересов в первую очередь беднейших слоев деревi ни. В совокупности с крайне скудными статьями бюджета республики, выделяемыми на развитие сельского ху хозяйства, это свидетельствовало о том, что проблемы крестьянского населения государственная власть стремилась решать за счет перераспределения средств от имущих к неимущим. Основная налоговая нагрузка при этом ложилась на самую инициативную и крепкую часть села - середняков и зажиточных, что в результате нивелировало все попытки ликвидировать крестьянские задолженности и перенаправить финансовые () потоки на техническое перевооружение деревни и интенсификацию сельскохозяйственного производства.
\end{abstract}


Ключевые слова: немецкое крестьянство, сельскохозяйственное производство, землеустройство, неурожайные годы, кантонное руководство.

Цитирование. Фурман Е. Л. Крестьянство Республики немцев Поволжья в период новой экономической политики // Вестник Волгоградского государственного университета. Серия 4, История. Регионоведение. Международные отношения. - 2017. - Т. 22, № 3. - C. 112-125. - DOI: https://doi.org/10.15688/jvolsu4.2017.3.10.

Возросший в конце 1980-х гг. интерес к истории российских немцев поддерживается на высоком уровне и в современных научных изысканиях. При этом история становления и своеобразие развития немецких колоний Поволжья являются неотьемлемой составляющей истории немецкого этноса в России [4; $12 ; 43 ; 44]$.

Население немецких колоний Поволжья, до революционных событий 1917 г. представленное в основном крестьянством, и после Октябрьского переворота по образу жизни, хозяйственному укладу и мировосприятию в большинстве своем было тесно связано с аграрным сектором.

Революция, годы Гражданской войны для населения немецких колоний Поволжья стали настоящим испытанием. Только за период с 1918 по 1921 г. из региона проживания немцев Поволжья в процессе реализации продовольственной разверстки и реквизиций было вывезено более 37 млн пудов продовольствия [5, с. 22]. При этом вследствие засухи в 1920 г. область постиг неурожай, следующий 1921 г. был также неурожайным. Обрушившийся голод был самым страшным: к 1 января 1922 г. в Области немцев Поволжья (ОНП) голодало $95 \%$ населения [5, с. 22]. В решении назревших проблем ощутимую помощь крестьянским хозяйствам оказала кооперация, еще усилиями царского правительства превращенная в государственный распределительный аппарат. Деятельность Комиссии помощи голодающим, созданной в 1921 г., помощь иностранных организаций едва покрывали катастрофический продовольственный дефицит, который продолжал ощущаться в области и на протяжении 1923 г. [29, с. 574-575, 578-579].

Несмотря на роспуск 15 октября 1922 г. ЦК Помгола и его местных органов, а следом, с 1 августа 1923 г., и комиссии по борьбе с последствиями голода и ее региональных отделений [29, с. 556, 572, 586; 31, л. 4 об.], усиленные поставки продовольственной помощи (при участии Американской администра- ции помощи (AРА), Международного союза помощи детям (МСПД), Евангелическо-лютеранского консилиума и др. организаций) в регионы, пораженные голодом, и в частности в Область немцев Поволжья, свидетельствовали: на местах бороться с голодом приходилось и в 1923 г. [16, с. 80]. Иностранная помощь направлялась в детдома, больницы, во многих селах при участии иностранных организаций открывались столовые. Отказываясь от широкомасштабной помощи голодающим, государство, тем не менее, держало под жестким контролем иностранные организации, которые продолжали участвовать в поддержке голодающих регионов [4, с. 124-126; 29 , c. 444-445, 534-535]. К концу лета 1923 г. иностранная поддержка голодающих регионов была фактически свернута. К осени 1923 г. действовало только «распределение частных продовольственных посылок» через систему складов АРА, имевшихся практически во всех крупных городах России [29, с. 590-591].

Между тем голод и практически полное отсутствие сельскохозяйственного инвентаря и рабочего скота в большинстве хозяйств области поставили крестьян перед необходимостью объединения в коллективные хозяйства. В 1919 г. в ОНП насчитывалось 4 колхоза, в 1920 году - 6 [34, л. 213], (к концу года 9: 2 коммуны и 7 сельскохозяйственных артелей [6, с. 232-233]), в 1921 г. - 23, в 1922 г. - 61 [34, л. 213-214]. Наивысшей точки развития колхозное движение в масштабах страны достигло в 1922 г. (16 000 колхозов), но уже в 1923 г. отмечалось снижение темпов колхозного строительства (12 773) [41, с. 73]. Несмотря на постоянную поддержку и активную агитацию со стороны государства, а также пик колхозного строительства в 1921-1922 гг., распространение колхозов было обусловлено, в первую очередь, голодом. Разоренные крестьянские хозяйства, лишенные рабочего скота, семенного фонда и сельхозтехники, вынуждены были вступать в колхозы, соединяя усилия и средства в ожидании следующего урожая. 
Примером, иллюстрирующим этот вывод, могут служить районы преимущественного распространения колхозов - больше всего в 1921-1922 гг. они были распространены именно в голодающих районах: Поволжье, ЮгоВосток, Приуралье, Крым.

Наиболее наглядно падение благосостояния немецкого крестьянства в неурожайные годы демонстрируют данные о сокращении поголовья скота и посевных площадей. Так, с 1914 по 1923 г. общее поголовье скота в ОНП сократилось с 887000 до 336 000, то есть более чем в 2,5 раза [24, л. 148-149], сокращение посевных площадей с 1185000 в 1914 г. до 471000 в 1923 г. [24, л. 148]. Последующее восстановление посевных площадей в условиях замедленного процесса восстановления поголовья рабочего скота (в 1926 г. $45 \%$ от количества 1916 г.) приведет к повышению нагрузки на рабочий скот. Так, в 1926 г. на 1 голову рабочего скота приходилось 8 га, в то время как в 1916 г. - только 4,4 га. [1]. К категории безлошадных хозяйств относилось к 1923 г. $-54,3 \%$, в $1924-53,2 \%$, в 1925 г. 47,5 \% всех хозяйств Немреспублики [5, с. 50]

При этом восстановление количественных показателей общего поголовья скота к 1927 г. и посевных площадей (69 \% от уровня 1914 г.) не позволяет оценить качественного изменения посевного и племенного материала. Между тем если раньше основное внимание в крестьянских хозяйствах уделялось посевам пшеницы белотурки, то голодные 19191922 гг. заставили крестьян переориентироваться на посевы ржи и кормовых. В условиях сокращения поголовья рабочего скота, при общем сокращении посевных площадей, крестьянам приходилось расширять посевы под озимые (рожь, просо) и пропашные культуры [5, c. 44]. В 1917-1920 гг. в ОНП рожь составляла $26,3 \%$, пшеница - от 60,6 до $86,9 \%$ посевных площадей. Посевы пшеницы с 1919 по 1921 г. сократились соответственно с 379600 до 31100 десятин [4, с. 170; 5, с. 23; 28, л. 13].

В 1924 г. крестьянские хозяйства Поволжья вновь постиг неурожай, ставший следствием разразившейся в области засухи. Начался стихийный отток крестьянского населения, в памяти которого еще сохранились воспоминания о голодных 1919-1922 годах. В мае 1924 г. Немреспублику покинуло 1924 чело- века, в июне - 8666 , июле - 8995 , августе 3322 , сентябре - 979, октябре - 616. В итоге из республики уехало 25502 человека или $4,5 \%$ всего населения. К концу года вернулось лишь 7 \% уехавших [39, л. 31].

Предотвратить массовый отъезд крестьян за пределы АССР НП удалось во многом благодаря предпринятым центральным и республиканским правительствами мерам. Для борьбы с последствиями неурожая Немреспублика получила 3412240 руб. [5, с. 88], благодаря чему удалось предотвратить распродажу сельхозинвентаря, падеж скота и голод. Также правительством были организованы платные общественные работы по мелиорации. Существенную помощь крестьянским хозяйствам АССР НП оказывала также сельскохозяйственная кооперация, участвовавшая в распределении кредитов, сельхозинвентаря и техники. С 1924 по 1925 г. количество сельскохозяйственных кооперативов увеличилось с 199 до 373 [27, л. 6, 8].

Однако предоставляемая государством помощь выделялась преимущественно в виде ссуд (семенные) и кредитов (мелиоративные, землеустроительные, фуражные и др.), вследствие чего «внешний» долг Немреспублики возрос к 1925 г. до 6,5 млн руб. [5, с. 88]. При этом помощь государственных органов крестьянскому населению не всегда оказывалась доступной и своевременной. Так, семенная ссуда предоставлялась в первую очередь бедняцким хозяйствам, затем середняцким и в последнюю - основным поставщикам товарного хлеба: хозяйствам зажиточных крестьян. При этом процент по ссуде оказывался для крестьян чрезмерно высоким, $35 \%$, или 14 фунтов с пуда $(5,6$ кг с 16,3 кг) [31, л. 8]. Некоторые крестьянские хозяйства от подобной «помощи» старались отказываться. Например, для крестьян Старо-Полтавского кантона семенная ссуда доставлялась в кантонный центр, который находился на удалении 60 70 верст от некоторых сел. В результате зажиточные крестьяне, имевшие подводы и лошадей, при распределении семенной ссуды практически не учитывались, а бедняки, которым эта ссуда предназначалась, попросту не имели возможности ее доставить в хозяйство. $66 \%$ всей задолженности по Немреспублике числилось за безлошадными и одно- 
лошадными хозяйствами [5, с. 89]. Приведенный пример иллюстрирует внедрение классового принципа в русле общегосударственной политики, осуществлявшейся чаще всего вразрез с экономической целесообразностью. Значительная часть распределявшихся ссуд имела, таким образом, невозвратный характер: решением республиканских властей с бедняцких безлошадных хозяйств она списывалась, но с однолошадных уже взыскивалась полностью [32, л. 111 об.].

Кроме того, в вопросах переработки и реализации сельскохозяйственной продукции государственные предприятия далеко не всегда действовали в интересах сельских производителей. Так, например, крестьяне в процессе переработки зерновых зачастую старались обращаться к частным мукомолам, так как последние брали на 2 фунта меньше гарнцевой муки (процент за помол муки), чем на мельницах Госмельпрома $[31$, л. 5]. Тем более что на многих государственных мельницах, по свидетельствам с мест, «осели старые их владельцы в надежде в будущем вернуть национализированное имущество» [31, л. 5].

Животноводческие хозяйства страдали от неурожаев в меньшей степени, чем зерновые, в условиях зоны рискованного земледелия. После революции, в связи оскудением крестьянских хозяйств вследствие повторяющихся неурожаев, переработке молочных продуктов как перспективному направлению в сельскохозяйственном производстве в Немреспублике начинают уделять все большее внимание [46, S. 423-424]. До революции переработкой молока в колониях занимались в основном хозяйства меннонитов, издавна владевшие рецептами и способами приготовления высококачественного сыра (например, сыр сорта Бакштейн). Хозяйства меннонитов, расположенные в Заволжье на заливных лугах, получали возможность разведения хорошего кормового материала для скотоводческих хозяйств, специализирующихся на разведении племенного скота, спрос на который был очень высок начиная со второго десятилетия XX века. С приходом советской власти развитие племенного скотоводства осуществлялось уже в рамках сельскохозяйственной кооперации. С целью организации молочного дела в Немреспублику был приглашен специальный ин- структор в союз сельскохозяйственной кооперации немцев Поволжья (далее - Немсельскосоюз), а также организованы специализированные курсы [46, S. 423-424]. По первичной сети Немсельскосоюза в 1925 г. 18 кооперативных объединений имели 26 сыроваренных заводов [23, с. 68].

Системный характер мероприятия в области животноводства приобретают с учреждением в 1924 г. Семплемсоюза АССР НП первого специализированного сельскохозяйственного кооперативного союза [14, л. 15]. В области животноводства особое внимание уделялось восстановлению поголовья свиней, в частности разведению свиней йоркширской породы. Так, в 1925 г. Немсельскосоюз приступил совместно с Сельскосоюзом РСФСР к постройке Беконной фабрики в Покровске, введенной в эксплуатацию в 1926 году.

В неурожайный 1924 г. существенным подспорьем крестьянскому населению АССР НП стало также табаководство. Оно развивалось в немецких колониях с момента их основания, к середине XIX в. являлось одной из основных отраслей сельскохозяйственного производства в колониях. Немецкий табак пользовался высоким спросом на рынках Казани, Москвы, Оренбурга, Симбирска, Саратова, Вольска, Мензелинска, Астрахани и других городов, традиционно составляя существенную статью доходов немецких колонистов. Среди кантонов Немреспублики лидерство оставалось за Марксштадтским и Красноярским кантонами, как и до революции. Площадь посевов табака в этих кантонах в 1924 г. составила 952 десятины, 55,27 десятин приходилось на остальные кантоны республики. В Красноярском кантоне 76,3 \% населения занимались производством табака, в Марксштадтском - 39,8 \% [21, с. 75]. Производители табака не только сумели сохранить в 1924-1925 гг. свое хозяйство, но и некоторым образом расширить его. Стимулом для развития табаководства являлось еще и то, что производство табака практически не требовало применения рабочего скота, дефицит которого ощущался в республике до 1927 г. $[21$, c. 76$]$.

Однако повторяющиеся неурожаи в зоне рискованного земледелия требовали также разработки и внедрения системных агрокуль- 
турных мероприятий, снижающих зависимость крестьянского хозяйства от природных катаклизмов. Засоренность и засоленность почвы, обилие вредителей, недостаток влаги - вот лишь немногие проблемы, относящиеся к природным факторам, с которыми также приходилось сталкиваться крестьянству практически во всех селах республики. Между тем влияние неблагоприятных природных факторов усиливалось практиковавшимся во многих хозяйствах после Гражданской войны и голодных лет нерациональным способом ведения земледелия. Так, например, стремясь увеличить объемы сбора зерновых, крестьяне делали упор на яровую пшеницу, в то время как большее количество осадков в регионе выпадало в первой половине июля, когда для яровых посевов они были уже неактуальны. Кроме того, постоянное возделывание хлебов истощало почву, урожайность из года в год падала [8, л. 13].

По мнению агрономов, в таких условиях большее внимание стоило обращать на озимую рожь и пропашные культуры (кукурузу, тыкву, подсолнечник), которые отличает больший период роста, совпадающий с сезоном июльских дождей. В случае неурожая эти культуры могли бы стать хорошим подспорьем в животноводческих хозяйствах. При этом организация столь необходимых в летние месяцы мелиоративных мероприятий оказывалась для многих крестьянских хозяйств слишком дорогим удовольствием. Так, в 1925-1926 гг. себестоимость мелиоративных мероприятий на 1 десятине достигала 120 руб. [9, л. 13 об.]. Голодные 1919-1923 гг. привели к тотальному оскудению крестьянских хозяйств немецкого Поволжья. Практиковавшийся в сложившихся условиях архаичный севооборот, низкосортные семена и отсутствие сельскохозяйственной техники отбросили крестьянские хозяйства поволжских немцев на несколько десятилетий назад.

Решить проблему оптимизации сельскохозяйственного производства, по мысли советского руководства, можно было путем проведения землеустроительных мероприятий. В условиях советской власти новые принципы организации сельскохозяйственного производства закреплялись законодательно целым рядом постановлений, начало которым было положено «Декретом о земле» 1917 года. Однако переход к нэпу в 1921 г. требовал согласования уже существовавшего земельного законодательства [8, с. 15-17, 37-48, 97-117 ${ }^{1}$ с новыми хозяйственными условиями, что нашло свое отражение в новом Земельном кодексе, принятом 30 октября 1922 года.

В соответствии с кодексом, все земли сельскохозяйственного назначения сводились в единый государственный земельный фонд, находившийся в ведении Наркомзема. Устанавливались следующие формы землепользования: общинное с уравнительными переделами между дворами, участковое (отрубные и хуторские участки) и товарищеское (сельскохозяйственная коммуна, артель, товарищество по совместной обработке земли) [15].

Проводившаяся советскими органами власти практика землеустройства в общих чертах следовала традициям Столыпинской аграрной реформы: ликвидация малоземелья и дальноземелья, чересполосицы, сведение разрозненных крестьянских участков к одному, введение многопольного севооборота и общего плана землепользования, кооперирование населения и др. Новаторскими являлись лишь терминология и идеологический крен - попытка внедрить в процессе организации землеустроенных групп классовый принцип [34, л. 220].

Однако процедура землеустройства, осуществлявшаяся специалистами отделов землеустройства при кантземуправлениях (организовывались с весны 1923 г. на территории ОНП), для многих хозяйств оказывалась очень дорогостоящей. Так же как и во времена осуществления Столыпинской реформы, ощущался заметный дефицит специализированных кадров [9, л. 12 об.]. Так, например, за 1924-1925 гг. села Палласовского кантона задолжали громадные суммы за проведенные землеустроительные работы. По свидетельству агронома Ю. Куфельда, к 1925 г. последние переделы земли в Палассовском кантоне производились 30 лет назад. В процессе проведения Столыпинской аграрной реформы к отрубам перешло большинство сел на площади 75 \% надельной земли (14922 956 десятин). После 1918 г. некоторые хозяйства уничтожили отруба, другие провели уравнение [9, л. 12]. В итоге, как и во многих других кантонах, образовалась путаница, которую лишь 
усугубил неурожай 1924 г. и стихийный отток крестьян из деревень.

В качестве ориентира для сел Немреспублики при осуществлении землеустроительных работ был принят на вооружение тип землеустройства, проведенного в Марксштадтском кантоне, где осуществлялось оформление групп по хозяйственной мощности в виде длинных полос по 60-70 верст, вокруг села, с удалением не более 10 верст [26, л. 11 об.; 44, c. 200]. Причем группы крестьянских хозяйств, оформленные до 1926 г., без учета классовых принципов, квалифицировались, как «лжегрупповое землеустройство» [22, л. 86].

К 1927 г. в АССР НП землеустроительные работы были осуществлены на площади 616570 га (в том числе межселенное на площади 159478 га, внутриселенное - 457092 га). Если учесть, что общая площадь удобной земли в Немреспублике составляла 1952969 га [1], то площадь, на которой были осуществлены землеустроительные работы, составила $31 \%$. Наибольшее распространение получило внутриселенное групповое землеустройство по классовому принципу (73,5 \%), поселковое $(3,4 \%)$, отрубное (1\%) и др. [26, л. 155-156].

Не имея средств для проведения землеустроительных работ, крестьяне зачастую самостоятельно захватывали бывшие частновладельческие земли. До определенного момента руководство закрывало глаза на эту практику [18, л. 30; 31, л. 46], осознавая, что противодействие самочинным крестьянским захватам приведет к общему сокращению посевной площади и ослаблению крестьянских хозяйств.

Проблему земельного дефицита республиканское руководство планировало разрешить выделением земель из госфонда Новоузенского уезда Саратовской губернии (около 500 тыс. десятин). Наиболее остро проблема ощущалась на территории нагорной стороны АССР НП (свыше 5000 хозяйств) [33, л. 181; 34 , л. 224]. Плотность населения на территории нагорной стороны АССР НП составляла от 42,4 до 52,4 жителей на одну квадратную версту (при средней по губерниям - 24 жителя) [5, с. 37]. Этот же фонд планировалось использовать для обеспечения землей потенциальных реэмигрантов из Америки (эмигрировавших колонистов Поволжья). Однако ини- циатива местных властей не увенчалась успехом [3, л. 69 об.].

Осуществлявшаяся государственными органами налоговая политика также не способствовала аккумуляции денежных средств в крестьянских хозяйствах. Декрет ВЦИК и СНК от 10 мая 1923 г. «О едином сельскохозяйственном налоге» в целях облегчения положения крестьянства объединял все государственные прямые налоги (трудгужналог, продналог, подворный, денежный), а также местные налоги в единый прямой сельскохозяйственный налог [7, ст. 42, с. 451]. К концу 1923 г. единый сельскохозяйственный налог (далее - ЕСХН) полностью переводился в денежное исчисление. Несмотря на изначально положительную идею консолидации крестьянских платежей, практическая ее реализация в условиях преимущественного учета интересов бедняцких слоев населения, а также коллективных хозяйств превращала ЕСХН в средство давления на так называемые зажиточные слои деревни, то есть в реальности на самых предприимчивых и крепких крестьян. К 1926 г. от выплаты сельхозналога были освобождены $33 \%$ всех хозяйств республики, относившихся к категории беднейших [30, л. 154]. Так, например, крестьянин с. Визенмиллер Старо-Полтавского кантона Буксман Иван Иванович, семья которого насчитывала три человека, уплачивал ЕСХН в размере 33 руб. 96 копеек. При этом в хозяйстве Буксмана насчитывалось 8,5 десятин посева, 7 коров, имелся доход от мельницы $[17$, л. 83]. Долг по ЕСХН только за 1927 г. по крестьянским хозяйствам Немреспублики исчислялся в 1 млн 550 тыс. руб., не считая распределенной среди крестьян семенной ссуды в объеме 1378450 пудов зерна [24, л. 159]. Кроме того, за крестьянами Немреспублики к исходу 1927 г. числились также долги за проведенные землеустроительные работы на сумму 327893 руб. 82 коп. [26, л. 155]. Принимая во внимание то, что селекционная семссуда распространялась весной 1927 г. преимущественно среди беднейшего крестьянства, она автоматически переходила также в разряд недоимок. Вся тяжесть уплаты налогов, следовательно, ложилась на зажиточные и середняцкие хозяйства - основных поставщиков товарного хлеба в деревне. 
При этом вследствие завышения норм доходности хозяйств отдельных кантонов, установленных СНК РСФСР для Немреспублики, возрастал и общий объем налоговых выплат. Так, к первой группе были отнесены кантоны, в которых норма доходности с десятины составляла 26 руб. (Марксштадтский, Красноярский, Кукусский, Покровский, Франкский, Каменский, Бальцерский). Во вторую группу были включены кантоны с нормой доходности 23 руб. с десятины посева (Мариентальский, Федоровский, Краснокутский, Золотовский) и в третью - с нормой доходности 20 руб. (Палласовский, Старо-Полтавский, Зельманский) [36, л. 65]. С бахчевых культур в среднем по АССР НП устанавливалась норма 150 руб., с фруктовых садов - 120 руб., посевов табака - 200 руб. с десятины [36, л. 66], что, соответственно, влекло за собой автоматически и повышение налоговых ставок с крестьянских хозяйств. Попытка Наркомфина АССР НП защитить крестьянство и предложить свои нормы расчета с учетом реальной доходности не увенчалась успехом.

В итоге в рамках разработанных нормативов почти $70 \%$ крестьянских хозяйств республики квалифицировались в отчетной документации как крепкие и платежеспособные по ставкам налогообложения. При этом к 1927 г., по данным статистики, только в 7,8 \% всех хозяйств республики использовался наемный труд [24, л. 153], в $2,7 \%$ хозяйств насчитывалось 4 и более голов рабочего скота и только $8 \%$ хозяйств имели в своем распоряжении от 13 до 25 и выше десятин посева [5, с. 50-51].

Для большей плановости в процессе сбора различных налоговых недоимок с крестьянского населения в соответствии с инструкцией, разработанной СНК РСФСР 21 апреля 1926 г., организовывались специальные комиссии в составе председателя кантонного исполкома, заведующего земотделом, завкантфинотделом, председателя крестьянского общества взаимопомощи, а также агента Госстраха [30, л. 161]. Организованная комиссия, кроме выявления недоимок и составления сводных списков недоимщиков, занималась также организацией изъятия имущества должников и последующей его реализацией.

При этом крестьяне, стараясь избежать максимальных выплат или по возможности их минимизировать, прибегали к дроблению хозяйств, скрытым посевам и др. Так, к 1927 г. количество крестьянских хозяйств по кантонам АССР НП увеличилось в среднем на 9,8 \% $[25$, л. 146]. В реальности это дробление являлось не более чем юридической уловкой крестьян, возможным способом борьбы с повышенным налогообложением.

Принимая во внимание то, что в бюджете АССР НП на развитие сельского хозяйства выделялось в 1922/23 г. 4 \%, в 1923/24 г. - 2,5 \%, в неурожайный 1924/25 г. - 4 \%, в 1927/28 г. $7 \%$ (для сравнения на просвещение в 1927 г. выделялось $35 \%$, на содержание административного аппарата - 20 \%) [24, л. 164], становится очевидным: разрешение проблемы финансирования сельского хозяйства перекладывалось на плечи самого крестьянства путем перераспределения финансовых потоков от имущих к неимущим.

Между тем введенные в 1925 г. волостные или сельские бюджеты, на которые из ставки единого сельхозналога страны (280 млн руб.) передавалось 100 млн руб., все равно оказались в итоге дефицитными. Так, в 19241925 гг. сельские бюджеты были введены в 251 селе Немреспублики. Общий доход всех сельских бюджетов составил 156464 руб., расход - 158000 рублей. В 1926-1927 гг. общий доход 288 сел Немреспублики составил 770800 руб., расход - 773300 руб. [25, л. 165]. Очевидно, что ставка на безвозвратное финансирование маломощных крестьянских хозяйств обрекала сформированные сельские бюджеты на постоянный дефицит средств.

Сельскохозяйственная кооперация, которая могла бы помочь крестьянству в условиях оптимально организованной кредитной политики, также была обременена значительными долгами, кардинально сужавшими оборотные средства и, как следствие, производственные возможности. Так, в 1926 г. собственные средства в низовой сети сельскохозяйственной кооперации составляли к балансу всего лишь 15,1 \% [45, с. 71]. В результате в условиях существования республиканских союзов кооперации (Немобсоюз, Немсельскосоюз, Немкустпромсоюз), входивших в общесоюзные центры кооперации, среди крестьянского населения республики поддерживалась идея создания экстерритори- 
ального национального крестьянского союза [11, л. 17; 38, л. 17].

Степень доверия населения к новой власти во многом иллюстрировалась практически полным безразличием к возможности вступления в ряды ВКП (б). Так, к концу 1926 г. на территории Немреспублики насчитывалось всего 2297 членов и кандидатов в члены ВКП (б), из них немцев - 705 человек, или $30,7 \%$ от общего количества [4, с. 208]. Низкий уровень членства в партии также во многом объяснялся сохранявшимся значительным влиянием церкви среди крестьянского населения Немповолжья. Так, в первой половине 1920-х гг., по свидетельствам с мест, в некоторых школах шульмейстеры возобновляли преподавание Закона Божьего [19, л. 2021]. Религиозное просвещение детей проводилось зачастую под видом подготовки к конфирмации [2, л. 43; 13, л. 10]. Между отдельными селами даже разворачивались настоящие соревнования за право проведения на своей территории очередной религиозной конференции или собрания, которых, по данным кантонного руководства, за зимний сезон могло проходить до 10 [35, л. 11].

Можно согласиться с мнением исследовательницы В.Г. Чеботаревой: «Партийное и советское руководство республики ничего не добилось в идеологическом плане - немецкое крестьянство продолжало оставаться под влиянием сельской буржуазии и священнослужителей разных конфессий, в полном соответствии с исторической традицией» [44, с. 206].

При этом позиция советских органов власти действительно для крестьянского населения далеко не всегда являлась очевидной. Так, в 1928 г. в с. Колышкино Старо-Полтавского кантона проживал Михаил Пятаков, в прошлом райпродкомиссар, затем один из лидеров крестьянского повстанческого движения в Поволжье в 1921 году. Данный факт вызывал по меньшей мере недоумение у местного населения, пострадавшего в свое время от рук банд Пятакова-Вакулина. Предпринимались попытки самосуда над Пятаковым, который продолжал спокойно вести свое хозяйство на глазах у местного населения, принимать своих бывших «подельников» из соседних сел [10, л. 12, 60]. В то же время из секретной переписки Старополтавского канткома и обкома
АССР НП становится очевидным, что М. Пятаков был оставлен и действовал в кантоне как осведомитель органов ГПУ [10, л. 60].

Между тем кризис хлебозаготовок 1927 г. предопределил судьбу советского крестьянства и облегчил принятие решения о кардинальной смене политико-экономического курса в стране. XV съезд ВКП (б), съезд коллективизации сельского хозяйства, сформулировал основную задачу государственной власти в деревне - задачу производственного кооперирования крестьянства и, как следствие, нажим на «классово чуждые» элементы в деревне (см.: [37, с. 680-695]). По данным Народного комиссариата земледелия СССР, на территории АССР НП к 15 декабря 1929 г. из 12 кантонов 8 было коллективизировано на 50-70 \%, к 20 апреля 1931 г. в среднем по республике коллективизации подверглось 88,6 \% крестьянских хозяйств (три кантона: Зельманский, Франкский и Каменский были коллективизированы уже на 100 \%) [20, л. 9]. Существовавшие на территории АССР НП колхозы объединяли к февралю 1930 г. в основном крестьянские хозяйства $(52,4 \%)$, выплачивающие сельхозналог с надбавками, то есть хозяйства середняков (см. подробно: [40, л. 90; 42, с. 58-64]).

Таким образом, можно отметить, что положение крестьянства АССР НП в период нэпа в первую очередь было обусловлено ориентацией государственной политики в крестьянском вопросе на учет интересов преимущественно беднейших слоев деревни. В результате в условиях неудовлетворительного государственного финансирования основные инвестиции в сельское хозяйство осуществлялись за счет налогообложения зажиточных и середняков, к которым советская власть в рамках существовавшей системы налогообложения отнесла большую часть крестьянского населения немецкой республики (почти 70 \%). При этом устоявшееся представление о крепких немецких аграриях, несмотря на оскудение немецкой деревни в условиях повторяющихся неурожаев и голода 1919-1924 гг. и стремительного снижения уровня аграрной культуры Немповолжья, обусловило и выбор подходов в практике налогообложения немецкого крестьянства. Завышенные нормы доходности крестьянских хозяйств и, как следствие, повышенное нало- 
гообложение, осуществлявшееся без учета реальной платежеспособности крестьянских хозяйств Немреспублики, подрывали не только их финансовую основу, но и доверие крестьян к советской власти в целом. Попытки ухода крестьян от налоговых выплат или их максимального снижения, низкий уровень членства в партии при сохранении влияния церкви в немецкой деревне доказывали низкий уровень общественного доверия к новой власти.

\section{ПРИМЕЧАНИЯ}

1 К первым декретам советской власти относился декрет «О земле» от 26 октября 1917 г., отменявший частую собственность на землю и вводивший уравнительное землепользование (по трудовой норме). Декрет, имевший временный характер, определял основные принципы землепользования и требовал максимальной детализации. В последующие годы будет принят целый ряд декретов и положений, регулирующих поземельные отношения в стране и общие принципы развития сельского хозяйства, к которым в первую очередь относим: декрет ВЦИК от 27 января 1918 г. «О социализации земли», Постановление ВЦИК от 14 февраля 1919 г. «О социалистическом землеустройстве и мерах перехода к социалистическому земледелию» и др.

\section{СПИСОК ЛИТЕРАТУРЫ}

1. Автономная Социалистическая Советская Республика немцев Поволжья //Атлас Союза Советских Социалистических Республик. - М. : Изд. ЦИК СССР, 1928. - 108 с. - Электрон. текстовые дан. - Режим доступа: http://istmat.info/node/39972 (дата обращения: 30.03.2017). - Загл. с экрана.

2. «Всем сельсоветам»: секретный циркуляр Старополтавского кантисполкома АССР НП от 19 мая 1926 г. // Центр документации новейшей истории Волгоградской области (далее - ЦДНИВО). Ф. 10487. - Оп. 1. - Д. 68.

3. Выписка из протокола № 13 заседания комфракции СНК АССР НП от 20 мая 1926 г. // ЦДНИВО. - Ф. 10474. - Оп. 1. - Д. 72.

4. Герман, А. А. Немецкая автономия на Волге, 1918-1941 / А. А. Герман. -2-е изд. - М. : МСНКпресс, 2007. - 576 с.

5. Гросс, Э. Автономная социалистическая советская республика немцев Поволжья / Э. Гросс. Покровск : Немиздат, 1926. - 125 с.

6. Данные статистики Наркомзема РСФСР о состоянии коллективных хозяйств на 1 декабря
1920 г. // Кооперативно-колхозное строительство, 1917-1922 гг. : док. и материалы. - М. : Наука, 1990. $400 \mathrm{c}$.

7. Декрет ВЦИК и СНК от 10 мая 1923 г. «О едином сельскохозяйственном налоге» // Собрание Узаконений РСФСР. - 1923. - Ст. 42. - С. 451.

8. Директивы КПСС и Советского правительства по хозяйственным вопросам : сб. док. 19171928 гг. - М. : Изд-во полит. лит., 1957. - Т. 1. - 879 с.

9. Доклад агронома Ю. Куфельда «Положение сельского хозяйства Палласовского кантона и перспективы дальнейшего развития» на заседании $\mathrm{V}$ съезда советов кантонов АССР НП. Январь 1925 г. // ЦДНИВО. - Ф. 10474. - Оп. 1. - Д. 67.

10. Докладная записка Старополтавского канткома ВКП (б) ответственному секретарю обкома Немреспублики тов. Вегнеру [1929]. Секретно // ЦДНИВО. - Ф. 10487. - Оп. 1. - Д. 136.

11. Доклад ответственного инструктора ЦК РКП (б) АССР НП тов. Квиринга по итогам обследования Автономной республики немцев Поволжья от 17.07.1925 // Российский государственный архив социально-политической истории (далее РГАСПИ). - Ф. 17. - ОП. 69. - Д. 26.

12. Ерина, Е. М. Очерки истории культуры Немецкой автономии на Волге / Е. М. Ерина. - Саратов : Изд-во Сарат. ун-та, 1995. - 112 с.

13. Заседание бюро обкома ВКП (б) от 29 марта 1926 г.: о допущении религиозного обучения детей // ЏДНИВО. - Ф. 10487. - Оп. 1. - Д. 68.

14. Заседание Сельскосоюза по вопросу организации и принятия в члены Сельскосоюза Союза семенных и племенных товариществ АССР НП от 8 апреля 1924 г. // Российский государственный архив экономики (далее - РГАЭ). - Ф. 4106. - Оп. 3. - Д. 506.

15. Земельный кодекс РСФСР (Постановление ВЦИК от 30 октября 1922 г.). - Электрон. текстовые дан. - Режим доступа: http://kadastr61.ru/biblioteka/ 7-kodeksy/116-30-1922.html (дата обращения: 15.01.2017). - Загл. с экрана.

16. Из госинформсводки информотдела ГПУ № 56 (585). 8 марта 1923 г. // Советская деревня глазами ВЧК - ОГПУ - НКВД, 1918-1939 : док. и материалы : в 4 т. / под ред. В. Данилова. - М. : РОССПЭН, 2000. - Т. 2. -1168 c.

17. Из закрытого письма ответственного секретаря Старо-Полтавского кантисполкома т. Гришина в Обком ВКП (б) АССР НП [1927] // ЦДНИВО. Ф. 10487. - Оп. 1. - Д. 68.

18. Из отчета о деятельности Палласовского канткома АССР НП в период неурожая 1924 г. // ЦДНИВО. -Ф. 10474. - Оп. 1. - Д. 31.

19. Из секретной переписки Старополтавского канткома с обкомом РКП (б) ОНП от 1 февраля 1923 г. // ЦДНИВО. - Ф. 10487. - Оп. 1. - Д. 22. Л. 20-21. 
20. Информсводка о ходе коллективизации по АССР НП на 20 апреля 1931 г. // РГАЭ. - Ф. 7446. Оп. 2. - Д. 565.

21. Каппес, С. Табаководство в Автономной Советской Социалистической Республике Немцев Поволжья / С. Каппес // Нижнее Поволжье. - 1925. № 4. - С. 75-76.

22. Краткий обзор о работе в немецкой деревне ячеек и национальных групп по Немреспублике. Март 1927 г. // ЦДНИВО. - Ф. 10487. - Оп. 1. - Д. 98.

23. Куфельд, Ю. Результаты в области сыроварения и маслоделия / Ю. Куфельд // Голос НижнеВолжского кооператора. - 1926. - № 9. - С. 68-70.

24. Отчет Обкома ВКП (б) АССР НП за период c XIV до XV партконференции. [Апрель - декабрь 1927 г.] // ЦДНИВО. - Ф. 10487. - Оп. 1. - Д. 98.

25. Отчетный доклад бюро Обкома ВКП (б) АССР НП о проделанной работе на заседании пленума ОК ВКП (б) от 14 июня 1928 г. // ЦДНИВО. Ф. 10487. - Оп. 1. - Д. 124.

26. Отчет Обкома ВКП (б) АССР НП о проведении землеустроительных работ [1927 г.] // ЦДНИВО. Ф. 10487. - Оп. 1. - Д. 98.

27. Отчет о деятельности Немсельскосоюза за 1923/24 гг. // РГАЭ. - Ф. 4106. - ОП. 3. - Д. 222.

28. Очерк развития сельского хозяйства в Автономных республиках и областях за 1922 г. и замечания по отчетам специалистов Федерального комитета по земельному делу при президиуме ВЦИК // Государственный архив Российской Федерации (далее ГАРФ). - Ф. Р-3260. - Оп. 3. - Д. 185.

29. Поляков, В. А. Голод в Поволжье, 19191925 гг.: происхождение, особенности, последствия / В. А. Поляков. - Волгоград : Волгогр. науч. изд-во, 2007. $-735 \mathrm{c}$.

30. Приложение к протоколу № 9 Пленума ОК ВКП (б) АССР НП от 12-14 октября 1926 г. // ЦДНИВО. - Ф. 10474. - Оп. 1. - Д. 72.

31. Протокол III съезда советов Палласовского кантона ОНП. 7-9 ноября 1923 г. // ЦДНИВО. Ф. 10474. - Оп. 1. - Д. 27.

32. Протокол заседания бюро Обкома ВКП (б) АССР НП от 16 августа 1926 г.: о взыскании семенной ссуды с крестьянских хозяйств АССР НП // ЦДНИВО. - Ф. 10474. - Оп. 1. - Д. 72.

33. Протокол заседания бюро Обкома ВКП (б) АССР НП от 24 ноября 1926 г.: о выделении земель крестьянским хозяйствам нагорной стороны АССР НП из Госфонда Новоузенского уезда Саратовской губернии // ЦДНИВО. - Ф. 10474. - Оп. 1. - Д. 72.

34. Протокол заседания бюро Обкома ВКП (б) АССР НП от 23 декабря 1926 г.: о реэмигрантах из Америки // ЦДНИВО. - Ф. 10474. - Оп. 1. - Д. 72.

35. Протокол заседания президиума Старополтавского кантисполкома АССР НП от 30 марта 1926 г.: копия проекта «Об устройстве собраний, связанных с выполнением религиозных обрядов» // ЦДНИВО. - Ф. 10487. - Оп. 1. - Д. 68.

36. Протокол заседания пленума Обкома ВКП (б) АССР НП от 24 февраля 1926 г.: нормы доходности по кантонам АССР НП // ЦДНИВО. - Ф. 10474. Оп. 1. - Д. 72.

37. Резолюция XV съезда ВКП (б) «О работе в деревне» от 19 декабря 1927 г. // Решения партии и правительства по хозяйственным вопросам, $1917-$ 1928. - М. : Изд-вополит. лит., 1967. - Т. 1.-С. 680-695.

38. Резолюция бюро Обкома ВКП (б) по вопросу о политическом состоянии Немреспублики от 25 января 1926 г. // ЦДНИВО. - Ф. 10474. - Оп. 1. Д. 72 .

39. Сведения о выселении из АССР НП и возвращении во время летней паники 1924 г. (из протокола заседания комиссии Обкома ВКП (б) по борьбе с недородом) // ЦДНИВО. - Ф. 10474. - Оп. 1. Д. 67.

40. Состояние коллективизации в Немреспублике в 1929-1930 гг. // РГАЭ. - Ф. 7446. - ОП. 2. Д. 376.

41. Стручков, Т. Сельскохозяйственная кооперация, ее состояние и некоторые черты развития / Т. Стручков // Экономическое обозрение. - 1924. Вып. 2. - С. 70-75.

42. Фурман, Е. Л. «Как ломали НЭП»: раскулачивание и коллективизация крестьянских хозяйств в 1928-1930 годах в Автономной Советской Социалистической Республике немцев Поволжья / Е. Л. Фурман // Вестник Волгоградского государственного университета. Серия 4, История. Регионоведение. Международные отношения. - 2011. - № 2 (20). C. 58-64.

43. Фурман, Е. Л. Кооперативное движение в немецких колониях Поволжья (1906 - начало 1930-х гг.) / Е. Л. Фурман. - Волгоград : Изд-во ВолГУ, 2011. $332 \mathrm{c}$.

44. Чеботарева, В. Г. Государственная национальная политика в Республике немцев Поволжья / В. Г. Чеботарева. - М. : Обществ. Акад. наук рос. немцев, 1999. - 452 с.

45. Я. Р. Четвертый съезд уполномоченных Союза кооперации Немреспублики / Я. Р. // Голос Нижне-Волжского кооператора. - 1926. - № 10. C. $70-73$.

46. Enders, J. Kooperative Käsereien in unserer Republik / J. Enders // Unsere Wirtschaft. - 1924. № 14. - S. 423-424.

\section{REFERENCES}

1. Avtonomnaya Sotsialisticheskaya Sovetskaya Respublika nemtsev Povolzhya [The Volga German Autonomous Soviet Socialist Republic]. Atlas Soyuza Sovetskikh Sotsialisticheskikh Respublik [Atlas of the 
Union of Soviet Socialist Republics]. Moscow, Izd-vo TsIK SSSR, 1928. 108 p. URL: http: http://istmat.info/ node/39972. (accessed March 30, 2017).

2. «Vsem selsovetam»: sekretnyy tsirkulyar Staropoltavskogo kantispolkoma ASSR NP ot 19 maya 1926 g. [To "All Village Councils": a Secret Circular from the Old-Poltava Executive Commitee of Workers' Council of the ASSR of Volga Germans of May 19, 1926]. Tsentr dokumentatsii noveyshey istorii Volgogradskoy oblasti [Center of Documentation of the Contemporary History of the Volgograd Region], F. 10487, Op. 1, D. 68.

3. Vypiska iz protokola № 13 zasedaniya komfraktsii SNK ASSR NP ot 20 maya $1926 \mathrm{~g}$. [Extract from the Minutes no. 13 of the Meeting of the Communist Group of the Council of People's Commissars of the ASSR of Volga Germans of May 20, 1926]. Tsentr dokumentatsii noveyshey istorii Volgogradskoy oblasti [Center of Documentation of the Contemporary History of the Volgograd Region], F. 10474, Op. 1, D. 72.

4. German A.A. Nemetskaya avtonomiya na Volge 1918-1941 [German Autonomy in the Volga Region in 1918-1941]. Moscow, MSNK-Press, 2007. $576 \mathrm{p}$.

5. Gross E. Avtonomnaya sotsialisticheskaya sovetskaya respublika nemtsev Povolzhya [The Volga German Autonomous Soviet Socialist Republic]. Pokrovsk, Nemizdat Publ., 1926. 125 p.

6. Dannye statistiki Narkomzema RSFSR o sostoyanii kollektivnykh khozyaystv na 1 dekabrya 1920 g. [Statistical Data of People's Commissariat for Agriculture of RSFSR about the Condition of Collective Farms as of December 1, 1920]. Kooperativnokolkhoznoe stroitelstvo, 1917-1922 gg.: dok. i materialy [Cooperative and Collective-Farm Construction, 1917-1922: Documents and Materials]. Moscow, Nauka Publ., 1990. 400 p.

7. Dekret VTsIK i SNK ot 10 maya 1923 g. «O edinom selskokhozyaystvennom naloge» [Resolution of the All-Russian Central Executive Committee and Council of People's Commissars of May 10, 1923 "On a Single Agricultural Tax"]. Sobranie Uzakoneniy RSFSR, 1923, art. 42, p. 451.

8. Direktivy KPSS i Sovetskogo pravitelstva po khozyaystvennym voprosam: sb. dok. 1917-1928 gg. [Directives of the CPSU and the Soviet Government on Economic Issues]. Moscow, Izd-vo politicheskoy literatury, 1957, vol. 1.879 p.

9. Doklad agronoma Yu. Kufelda «Polozhenie selskogo khozyaystva Pallasovskogo kantona i perspektivy dalneyshego razvitiya» na zasedanii V syezda sovetov kantonov ASSR NP. Yanvar 1925 g. [Report of Agronomist Yu. Kufeld "The Condition of Agriculture in the Pallasovsky State Council and the Prospects for Further Development" at the Meeting of the $5^{\text {th }}$ Congress of Soviet Cantons of the ASSR of Volga Germans. January 1925]. Tsentr dokumentatsii noveyshey istorii Volgogradskoy oblasti [Center of Documentation of the Contemporary History of the Volgograd Region], F. 10474, Op. 1, D. 67.

10. Dokladnaya zapiska Staropoltavskogo kantkoma VKP (b) otvetstvennomu sekretaryu obkoma Nemrespubliki tov. Vegneru (1929). Sekretno [Memorandum of the Old-Poltava Canton Committee of the All-Union CP (b) to the Executive Secretary of the Regional Committee of the ASSR of Volga Germans of Comrade Wegener (1929). Secret Report]. Tsentr dokumentatsii noveyshey istorii Volgogradskoy oblasti [Center of Documentation of the Contemporary History of the Volgograd Region], F. 10487, Op. 1, D. 136.

11. Doklad otvetstvennogo instruktora TsK RKP (b) ASSR NP tov. Kviringa po itogam obsledovaniya Avtonomnoy respubliki nemtsev Povolzhya ot 17.07.1925 [Report of Responsible Instructor of the Central Committee of the All-Union CP(b) of the ASSR of Volga Germans Comrade Kviring Based on the Results of GA SSSR Survey of July 17, 1925]. Rossiyskiy gosudarstvennyy arkhiv sotsialno-politicheskoy istorii [Russian State Archive of Social and Political History], F. 17, Op. 69, D. 26.

12. Erina E.M. Ocherki istorii kultury Nemetskoy avtonomii na Volge [Essays on the History of Culture of the German Autonomy on the Volga]. Saratov, Izd-vo Sarat. un-ta, 1995. 112 p.

13. Zasedanie byuro obkoma VKP (b) ot 29 marta 1926 g.: o dopushchenii religioznogo obucheniya detey [Meeting of the Bureau of the Regional Committee of the All-Union CP (b) of March 29, 1926: on the Admission of Religious Education of Children]. Tsentr dokumentatsii noveyshey istorii Volgogradskoy oblasti [Center of Documentation of the Contemporary History of the Volgograd Region], F. 10487, Op. 1, D. 68.

14. Zasedanie Selskosoyuza po voprosu organizatsii i prinyatiya v chleny Selskosoyuza Soyuza semennykh i plemennykh tovarishchestv ASSR NP ot 8 aprelya $1924 \mathrm{~g}$. [Meeting of the Agricultural Union on the Issues of Organization and Admission to the Agricultural Union of the Union of Seminal and Tribal Associations of the ASSR of Volga Germans of April 8, 1924]. Rossiyskiy gosudarstvennyy arkhiv ekonomiki [Russian StateArchive ofEconomy], F. 4106, Op. 3, D. 506.

15. Zemelnyy kodeks RSFSR (Postanovlenie VTsIK ot 30 oktyabrya 1922 g.) [Land Code of RSFSR (Resolution of All-Russian Central Executive Committee of October 30, 1922)]. URL: http:// kadastr61.ru/biblioteka/7-kodeksy/116-30-1922.html (accessed January 12, 2017).

16. Iz gosinformsvodki informotdela GPU № 56 (585). 8 marta 1923 g. [From the State Secret Report of the Informational Chief of the Main Political Department no. 56 (585). March 8, 1923]. Sovetskaya 
derevnya glazami VChK - OGPU - NKVD, 19181939: dok. i materialy: v 4 t. [The Soviet Village through the Eyes of the Cheka - the OGPU - the NKVD. 1918-1939: Documents and Materials in 4 vols.]. Moscow, ROSSPEN Publ., 2000, vol. 2. 1168 p.

17. Iz zakrytogo pisma otvetstvennogo sekretarya Staro-Poltavskogo kantispolkoma t. Grishina v Obkom VKP (b) ASSR NP (1927) [From the Secret Letter of Responsible Secretary of the Old Poltava Canton Executive Committe Comrade Grishin to the Regional Committee of the All-Union CP (b) of the ASSR of Volga Germans (1927)]. Tsentr dokumentatsii noveyshey istorii Volgogradskoy oblasti [Center of Documentation of the Contemporary History of the Volgograd Region], F. 10487, Op. 1, D. 68.

18. Iz otcheta o deyatelnosti Pallasovskogo kantkoma ASSR NP v period neurozhaya 1924 g. [From the Report on the Activity of Pallasovsky cantonovo Committee all-Russian Communist Party of the ASSR of Volga Germans in Times of Crop Failure of 1924]. Tsentr dokumentatsii noveyshey istorii Volgogradskoy oblasti [Center of Documentation of the Contemporary History of the Volgograd Region], F. 10474, Op. 1, D. 31.

19. Iz sekretnoy perepiski Staropoltavskogo kantkoma s obkomom RKP (b) ONP ot 1 fevralya 1923 g. [From the Secret Correspondence of the Old-Poltava Canton Committee with the Regional Committee of the CP (b) of February 1, 1923]. Tsentr dokumentatsii noveyshey istorii Volgogradskoy oblasti [Center of Documentation of the Contemporary History of the Volgograd Region], F. 10487, Op. 1, D. 22.

20. Informsvodka o khode kollektivizatsii po ASSR NP na 20 aprelya 1931 g. [Information Summary on the Progress of Collectivization in the ASSR of Volga Germans as of April 20, 1931]. Rossiyskiy gosudarstvennyy arkhiv ekonomiki [Russian State Archive of Economy], F. 7446, Op. 2, D. 565.

21. Kappes S. Tabakovodstvo v Avtonomnoy Sovetskoy Sotsialisticheskoy Respublike Nemtsev Povolzhya [Tobacco Farming in the Volga German Autonomous Soviet Socialist Republic]. Nizhnee Povolzhye, 1925, no. 4, pp. 75-76.

22. Kratkiy obzor o rabote v nemetskoy derevne yacheek i natsionalnykh grupp po Nemrespublike. Mart 1927 g. [A Brief Overview about the Work of the German Village Cells and National Groups in the Republic of the Volga Germans. March 1927]. Tsentr dokumentatsii noveyshey istorii Volgogradskoy oblasti [Center of Documentation of the Contemporary History of the Volgograd Region], F. 10487, Op. 1, D. 98.

23. Kufeld Yu. Rezultaty v oblasti syrovareniya i maslodeliya [Results in the Field of Cheese Making and Butter Making]. Golos Nizhne-Volzhskogo kooperatora, 1926, no. 9, pp. 68-70.
24. Otchet Obkoma VKP (b) ASSR NP za period s XIV do XV partkonferentsii. Aprel-dekabr 1927 g. [Report of the Regional Committee of the All-Union CP (b) of the ASSR of Volga Germans for the Period from the $14^{\text {th }}$ to the $15^{\text {th }}$ Party Conference. AprilDecember, 1927]. Tsentr dokumentatsii noveyshey istorii Volgogradskoy oblasti [Center of Documentation of the Contemporary History of the Volgograd Region], F. 10487, Op. 1, D. 98.

25. Otchetnyy doklad byuro Obkoma VKP (b) ASSR NP o prodelannoy rabote na zasedanii plenuma OK VKP (b) ot 14 iyunya $1928 \mathrm{~g}$. [Report of the Bureau of the Regional Committee of the All-Union CP (b) of ASSR of Volga Germans on the Work of the Meeting of the Plenum of the regional Committee of the AllUnion CP (b) of June 14, 1928]. Tsentr dokumentatsii noveyshey istorii Volgogradskoy oblasti [Center of Documentation of the Contemporary History of the Volgograd Region], F. 10487, Op. 1, D. 124.

26. Otchet Obkoma VKP (b) ASSR NP o provedenii zemleustroitelnykh rabot. $1927 \mathrm{~g}$. [Report of the Regional Committee of the All-Union CP (b) of the ASSR of Volga Germans on Land Management. 1927]. Tsentr dokumentatsii noveyshey istorii Volgogradskoy oblasti [Center of Documentation of the Contemporary History of the Volgograd Region], F. 10487, Op. 1, D. 98.

27. Otchet o deyatelnosti Nemselskosoyuza za 1923/ $24 \mathrm{gg}$. [Report on the Activities of the German Union of Agricultural Cooperatives for 1923/24]. Rossiyskiy gosudarstvennyy arkhiv ekonomiki [Russian State Archive of Economy], F. 4106, Op. 3, D. 222.

28. Ocherk razvitiya selskogo khozyaystva $\mathrm{v}$ Avtonomnykh respublikakh i oblastyakh za 1922 g. i zamechaniya po otchetam spetsialistov Federalnogo komiteta po zemelnomu delu pri prezidiume VTsIK [Essay on the Development of Agriculture in the Autonomous Republics and Regions for 1922 and Remarks on Reports of Experts of the Federal Committee for Land Affairs under the Presidium of the All-Russian Executive Committee]. Gosudarstvennyy arkhiv Rossiyskoy Federatsii [State Archive of the Russian Federation], F. R-3260, Op. 3, D. 185.

29. Polyakov V.A. Golod v Povolzhye, 19191925 gg.: proiskhozhdenie, osobennosti, posledstviya [The Famine in the Volga Region, 1919-1925: Origin, Features, Consequences]. Volgograd, Izd-vo VolGU, 2007. 735 p.

30. Prilozheniek protokolu № 9 Plenuma OK VKP (b) ASSR NP ot 12-14 oktyabrya $1926 \mathrm{~g}$. [Annex to the Protocol no. 9 of the Plenum of the Regional Committee of the All-Union CP (b) of the ASSR of Volga Germans of October 12-14, 1926]. Tsentr dokumentatsii noveyshey istorii Volgogradskoy oblasti [Center of Documentation of the Contemporary History of the Volgograd Region], F. 10474, Op. 1, D. 72. 
31. Protokol III syezda sovetov Pallasovskogo kantona ONP. 7-9 noyabrya 1923 g. [Protocol III of the Congress of Councils of the Pallasovsky Canton of the Volga Germans Republic. November 7-9, 1923]. Tsentr dokumentatsii noveyshey istorii Volgogradskoy oblasti [Center of Documentation of the Contemporary History of the Volgograd Region], F. 10474, Op. 1, D. 27.

32. Protokol zasedaniya byuro Obkoma VKP (b) ASSR NP ot 16 avgusta 1926 g.: o vzyskanii semennoy ssudy s krestyanskikh khozyaystv ASSR NP [The Minutes of Session of Regional Committee Bureau of the All-Union CP (b) of the ASSR of Volga Germans of August 16, 1926: On Recovery of a Seed Loan from Peasant Farms of the ASSR of Volga Germans]. Tsentr dokumentatsii noveyshey istorii Volgogradskoy oblasti [Center of Documentation of the Contemporary History of the Volgograd Region], F. 10474, Op. 1, D. 72.

33. Protokol zasedaniya byuro Obkoma VKP (b) ASSR NP ot 24 noyabrya 1926 g.: o vydelenii zemel krestyanskim khozyaystvam nagornoy storony ASSR NP iz Gosfonda Novouzenskogo uezda Saratovskoy gubernii [The Minutes of Session of Regional Committee Bureau of the All-Union CP(b) of the ASSR of Volga Germans of November 24, 1926: on the Allocation of Lands to Peasant Farms of the Mountainous Side of the ASSR of Volga Germans from the State Fund of the Novouzensky District of the Saratov Province]. Tsentr dokumentatsii noveyshey istorii Volgogradskoy oblasti [Center of Documentation of the Contemporary History of the Volgograd Region], F. 10474, Op. 1, D. 72.

34. Protokol zasedaniya byuro Obkoma VKP (b) ASSR NP ot 23 dekabrya 1926 g.: o reemigrantakh iz Ameriki [The Minutes of Session of Regional Committee Bureau of the All-Union CP(b) of the ASSR of Volga Germans of December 23, 1926: on ReEmigrants from America]. Tsentr dokumentatsii noveyshey istorii Volgogradskoy oblasti [Center of Documentation of the Contemporary History of the Volgograd Region], F. 10474, Op. 1, D. 72.

35. Protokol zasedaniya prezidiuma Staropoltavskogo kantispolkoma ASSR NP ot 30 marta 1926 g.: kopiya proekta «Ob ustroystve sobraniy, svyazannykh s vypolneniem religioznykh obryadov» [The Minutes of Session of Presidium of Old Poltava Regional Committee of the All-Union CP (b) of the ASSR of Volga Germans of March 30, 1926: Copy of the Project "On Organization of Meetings Connected with Religious Rites"]. Tsentr dokumentatsii noveyshey istorii Volgogradskoy oblasti [Center of Documentation of the Contemporary History of the Volgograd Region], F. 10487, Op. 1, D. 68.

36. Protokol zasedaniya plenuma Obkoma VKP (b) ASSR NP ot 24 fevralya 1926 g.: normy dokhodnosti po kantonam ASSR NP [The Minutes of Session of Regional Committee Plenum of the OldPoltava Canton Executive Committee of the ASSR of Volga Germans of February 24, 1926: Profitability Norms in Cantons of the ASSR of Volga Germans]. Tsentr dokumentatsii noveyshey istorii Volgogradskoy oblasti [Center of Documentation of the Contemporary History of the Volgograd Region], F. 10474, Op. 1, D. 72.

37. Rezolyutsiya XV syezda VKP (b) «O rabote v derevne» ot 19 dekabrya $1927 \mathrm{~g}$. [The Resolution of the $15^{\text {th }}$ Congress of the All-Union CP (b) "About Work in the Village" of December 19, 1927]. Resheniya partii i pravitelstva po khozyaystvennym voprosam, 19171928 [Solutions of the Party and the Government on Economic Issues. 1917-1928]. Moscow, Izd-vo politicheskoy literatury, $1967.782 \mathrm{p}$.

38. Rezolyutsiya byuro Obkoma VKP (b) po voprosu o politicheskom sostoyanii Nemrespubliki ot 25 yanvarya $1926 \mathrm{~g}$. [Resolution of the Bureau of the Regional Committee of the CPSU (b) on the Political Situation of the Volga Germans Republic of January 25, 1926]. Tsentr dokumentatsii noveyshey istorii Volgogradskoy oblasti [Center of Documentation of the Contemporary History of the Volgograd Region], F. 10474, Op. 1, D. 72.

39. Svedeniya o vyselenii iz ASSR NP i vozvrashchenii vo vremya letney paniki 1924 g. (iz protokola zasedaniya komissii Obkoma VKP (b) po borbe s nedorodom) [Data on Eviction from the ASSR of Volga Germans and Resetting during the Summer Panic of 1924 (from the Minutes of the Session of the Regional Committee of the CPSU (b) on Crop Failure Prevention)]. Tsentr dokumentatsii noveyshey istorii Volgogradskoy oblasti [Center of Documentation of the Contemporary History of the Volgograd Region], F. 10474, Op. 1, D. 67.

40. Sostoyanie kollektivizatsii v Nemrespublike v 1929-1930 gg. [Condition of Collectivization in the ASSR of Volga Germans in 1929-1930]. Rossiyskiy gosudarstvennyy arkhiv ekonomiki [Russian State Archive of Economy], F. 7446, Op. 2, D. 376.

41. Struchkov T. Selskokhozyaystvennaya kooperatsiya, ee sostoyanie i nekotorye cherty razvitiya [Agricultural Cooperation, its Condition and Some Features of Development]. Ekonomicheskoe obozrenie. 1924, no. 2, pp. 70-75.

42. Furman E.L. «Kak lomali NEP»: raskulachivanie i kollektivizatsiya krestyanskikh khozyaystv v 1928-1930 godakh v Avtonomnoy Sovetskoy Sotsialisticheskoy Respublike nemtsev Povolzhya ["How to Break the NEP": Dispossession and the Collectivization of Farms in 1928-1930 in the Volga German Autonomous Soviet Socialist Republic]. Vestnik Volgogradskogo gosudarstvennogo universiteta. Seriya 4. Istoriya. Regionovedenie. 
Mezhdunarodnye otnosheniya [Science Journal of Volgograd State University. History. Area Studies. International Relations], 2011, no. 2 (20), pp. 58-64.

43. Furman, E.L. Kooperativnoe dvizhenie v nemetskikh koloniyakh Povolzhya (1906 - nachalo 1930-kh gg.) [The Cooperative Movement in the German Colonies of the Volga Region (1906 - early 1930s)]. Volgograd, Izd-vo VolGU, 2011. 332 p.

44. Chebotareva V.G. Gosudarstvennaya natsionalnaya politika $v$ Respublike nemtsev
Povolzhya [The State National Policy in the Republic of the Volga Germans]. Moscow, Academy of Sciences of Russian Germans, 1999. 452 p.

45. Ya. R. Chetvertyy syezd upolnomochennykh Soyuza kooperatsii Nemrespubliki [Fourth Congress of Representatives of the Union of Cooperation of the Volga Germans Republic]. Golos Nizhne-Volzhskogo kooperatora, 1926, no.10, pp.70-73.

46. Enders J. Kooperative Käsereien in unserer Republik. Unsere Wirtschaft, 1924, no. 14, pp. 423-424.

\section{Information About the Author}

Ekaterina L. Furman, Candidate of Sciences (History), Associate Professor, Department of History of Russia, Volgograd State University, Prosp. Universitetsky, 100, 400062, Volgograd, Russian Federation, ekaterina_furman@mail.ru, histrus@volsu.ru,http://orcid.org/0000-0001-7346-295X

\section{Информация об авторе}

Екатерина Львовна Фурман, кандидат исторических наук, доцент кафедры истории России, Волгоградский государственный университет, просп. Университетский, 100, 400062, г. Волгоград, Российская Федерация, ekaterina_furman@mail.ru, histrus@volsu.ru, http://orcid.org/00000001-7346-295X 